\begin{tabular}{|l|l|l||}
\hline \multicolumn{2}{|c|}{ PublisherInfo } \\
\hline \hline PublisherName & $:$ & BioMed Central \\
\hline \hline PublisherLocation & $:$ & London \\
\hline \hline PublisherImprintName & $:$ & BioMed Central \\
\hline \hline
\end{tabular}

\title{
Hemoglobin and malaria
}

\begin{tabular}{|l|l|l||}
\hline \multicolumn{2}{|c||}{ ArticleInfo } \\
\hline \hline ArticleID & $:$ & 4256 \\
\hline \hline ArticleDOI & $:$ & $10.1186 /$ gb-spotlight-20011120-01 \\
\hline \hline ArticleCitationID & $:$ & spotlight-20011120-01 \\
\hline \hline ArticleSequenceNumber & $:$ & 327 \\
\hline \hline ArticleCategory & $:$ & Research news \\
\hline \hline ArticleFirstPage & $:$ & 1 \\
\hline \hline ArticleLastPage & $:$ & 2 \\
\hline \hline & & RegistrationDate : 2001-11-20 \\
ArticleHistory & $:$ & OnlineDate $\quad$ 2001-11-20 \\
\hline \hline ArticleCopyright & $:$ & BioMed Central Ltd2001 \\
\hline \hline ArticleGrants & $:$ & \\
\hline \hline ArticleContext & $:$ & 130592211 \\
\hline \hline
\end{tabular}




\section{Jonathan B Weitzman}

Email: jonathanweitzman@hotmail.com

The human genome is under continuous selective pressure for resistance to infectious diseases. Several polymorphic alleles have been associated with resistance to malaria in West African populations, for example. In the November 15 Nature, Modiano et al. report a large-scale study aimed at clarifying the role of hemoglobin $\mathrm{C}(\mathrm{HbC})$ in resistance to Plasmodium falciparum malaria (Nature 2001, 414:305-308). They evaluated allele frequencies for the $\beta$ globin gene in 3,513 healthy subjects and 835 malaria patients in Burkina Faso. The results show that $\mathrm{HbC}$ can provide protection against $P$. falciparummalaria in both the heterozygous and homozygous states. The reduced risk is $93 \%$ for $\mathrm{HbCC}$ homozygosity and $29 \%$ for $\mathrm{HbAC}$ heterozygosity. The authors predict that the $\mathrm{HbC}$ alleles will spread across Africa, replacing the sickle hemoglobin (hemoglobin $\mathrm{S} ; \mathrm{HbS}$ ) polymorphisms that are associated with reduced fitness.

\section{References}

1. Sickle hemoglobin (HbS) allele and sickle cell disease: a HuGE review.

2. Nature, [http://www.nature.com] 